\title{
Modelling the permeability loss of metallic iron water filtration systems
}

Caré S. ${ }^{(\mathrm{a})}$, Crane R. ${ }^{(\mathrm{b})}$, Calabrò P.S. ${ }^{(\mathrm{c})}$, Ghauch A. ${ }^{(\mathrm{d})}$, Temgoua E. ${ }^{(\mathrm{e})}$, Noubactep C..$^{(\mathrm{f}, \mathrm{g}){ }^{*}}$

(a) UniversitéParis Est, Laboratoire Navier (ENPC/IFSTTAR/CNRS), 2 allée Kepler, F- 77420 Champs sur Marne, France (sabine.care@ifsttar.fr).

(b) Interface Analysis Centre, University of Bristol, 121 St. Michael's Hill, Bristol, BS2 8BS, UK. (Richard.Crane@bristol.ac.uk)

(c) Università degli Studi Mediterranea di Reggio Calabria, MECMAT, Mechanics and Materials Department, Faculty of Engineering, Via Graziella, loc. Feo di Vito, 89122 Reggio Calabria, Italy. (paolo.calabro@unirc.it)

(d) American University of Beirut, Faculty of Arts and Sciences, Department of Chemistry, P.O. Box 11-0236 Riad El Solh-1107-2020 Beirut, Lebanon. (ag23@aub.edu.lb)

${ }^{(e)}$ University of Dschang, Faculty of Agronomy and Agricultural Science, P.O. Box 222 Dschang, Cameroon. (emile.temgoua@univ-dschang.com)

${ }^{(\mathfrak{)})}$ Angewandte Geologie, Universität Göttingen, Goldschmidtstraße 3, D - 37077 Göttingen, Germany.

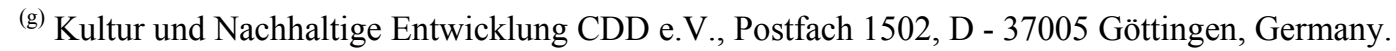

Correspond author; e-mail: cnoubac@gwdg.de; Tel. +49 551 39 3191, Fax. +49 551399379

\section{Abstract}

Over the past 30 years the literature has burgeoned with in-situ approaches for groundwater remediation. Of the methods currently available, the use of metallic iron $\left(\mathrm{Fe}^{0}\right)$ in permeable reactive barrier (PRB) systems is one of the most commonly applied. Despite such interest, an increasing amount of experimental and field observations have reported inconsistent $\mathrm{Fe}^{0}$ barrier operation compared to contemporary theory. In the current work, a critical review of the physical chemistry of aqueous $\mathrm{Fe}^{0}$ corrosion in porous media is presented. Subsequent implications for the design of $\mathrm{Fe}^{0}$ filtration systems are modelled. The results suggest that: (i) for the $\mathrm{pH}$ range of natural waters $(>4.5)$, the high volumetric expansion of $\mathrm{Fe}^{0}$ during oxidation and precipitation dictates that $\mathrm{Fe}^{0}$ should be mixed with a non-expansive material; (ii) naturally-occurring solute precipitates have a negligible impact on permeability loss compared to $\mathrm{Fe}^{0}$ expansive corrosion; and (iii) the proliferation of $\mathrm{H}_{2}$ metabolising bacteria 
may contribute to alleviate permeability loss. As a consequence, it is suggested that more emphasis must be placed on future work with regard to considering the $\mathrm{Fe}^{0} \mathrm{PRB}$ system as a physical (size-exclusion) water filter device.

Keywords: Deep-bed filtration, Hydraulic conductivity, Modelling, Permeability loss, Zerovalent iron.

\section{Acronym List}

ITRC Interstate Technology \& Regulatory Council

PRB Permeable reactive barrier

RZ Reactive Zone

ZVI Zerovalent iron

\section{Introduction}

Permeable reactive barriers containing metallic iron as a reactive filler material $\left(\mathrm{Fe}^{0} \mathrm{PRBs}\right)$ is an established technology for groundwater remediation [1-10]. At present, more than $120 \mathrm{Fe}^{0}$ PRBs have been installed worldwide, and effective performance has typically been reported [10-13]. $\mathrm{Fe}^{0} \mathrm{PRBs}$ typically contain either pure $\mathrm{Fe}^{0}$ or a mixture of $\mathrm{Fe}^{0}$ and another material, such as gravel or sand. The incorporation of a secondary material is typically employed either to meet design requirements, cost, or to limit permeability loss. In such cases, potential drawbacks on the kinetics of contaminant removal must be considered [14]. However, some available experimental results from batch $[15,16]$ and column [14,17] studies suggest that admixing pumice/sand to $\mathrm{Fe}^{0}$ is beneficial for the process of contaminant removal. Therefore, the recent statement of Ulsamer [13] that "there is no conclusive evidence that a sand/iron mix is better or worse than a pure iron barrier" can be considered the current state-of-the-art. In addition, the challenge of determining the fundamental mechanisms which govern hydraulic conductivity (permeability) loss is yet to be properly addressed $[10,11,13,18,19]$. At present it is suggested that the mechanism of permeability loss in $\mathrm{Fe}^{0} \mathrm{PRBs}$ is due to the 
accumulation of insoluble minerals within the PRB pore network [10,13]. Relevant minerals include siderite $\left(\mathrm{FeCO}_{3}\right)$, aragonite $\left(\mathrm{CaCO}_{3}\right)$, and iron (hydr)oxides (e.g. $\mathrm{Fe}(\mathrm{OH})_{2}, \mathrm{Fe}(\mathrm{OH})_{3}$, $\left.\mathrm{FeOOH}, \mathrm{Fe}_{2} \mathrm{O}_{3}, \mathrm{Fe}_{3} \mathrm{O}_{4}\right)$ [10,13,20-26]. Another mechanism reported attributes the permeability loss to the build-up of $\mathrm{H}_{2}$ gas, formed due to the hydrolysis of water during $\mathrm{Fe}^{0}$ corrosion $[11,27,28]$. However, as $\mathrm{H}_{2}$ is a key source of energy for numerous different microorganism species [23,29-31], the contribution of $\mathrm{H}_{2}$ to the process of $\mathrm{Fe}^{0} \mathrm{PRB}$ permeability loss has been ascribed as minor [32].

The theory that $\mathrm{Fe}^{0} \mathrm{PRB}$ permeability loss is predominantly due to the accumulation of insoluble minerals within pore volumes was recently challenged by Henderson and Demond [11]. The authors cited that whilst natural groundwater constituents (e.g. carbonates) and contaminant species can occur in subsurface concentrations of several hundred parts per million (or mg per litre), the mass/volume occupied by the mineral precipitates will be minor compared to the large amount required to significantly impair the permeability of an average permeable reactive barrier system. Based on this premise they attributed the permeability loss to the accumulation of $\mathrm{H}_{2}$ gas, and suggested periodical venting to prevent build-up. All studies to date, however, have overlooked the role of the volumetric expansive iron corrosion products [33-36] in PRB permeability loss.

In the current work, a multidisciplinary theoretical approach has been applied to analyse the relationship between the extent of $\mathrm{Fe}^{0}$ depletion and permeability loss in $\mathrm{Fe}^{0}$ beds (including water filters and PRBs), by linking: contemporary knowledge of the mechanisms which govern contaminant removal by $\mathrm{Fe}^{0}$ [37]; with mathematical modelling mass conservation equations. Much of the impetus for this work originates from recent work summarized in Noubactep et al. [38] wherein the advantages of admixing non-expansive materials to $\mathrm{Fe}^{0}$ within $\mathrm{Fe}^{0}$ filtration systems are discussed. For the sake of clarity, the basic conservation equation for the oxidative dissolution of iron will be given.

\section{$2 \quad$ Conservation equation of iron corrosion at $\mathrm{pH}>4.5$}




\subsection{Basic conservation equation}

The basic constitutive equation expressing the overall conservation of mass of any chemical element $(j)$ consumed in a chemical reaction relates volume (V), dry bulk density $(\rho)$, and chemical composition (C) and mass fluxes (m) into or out of a system [39]:

$$
\mathrm{V}_{\mathrm{p}} \rho_{\mathrm{p}} \mathrm{C}_{\mathrm{j}, \mathrm{p}} / 100+\mathrm{m}_{\mathrm{j}, \mathrm{flux}}=\mathrm{V}_{\mathrm{w}} \rho_{\mathrm{w}} \mathrm{C}_{\mathrm{j}, \mathrm{w}} / 100
$$

The first term of Eq. 1 expresses the mass of element $\mathrm{j}$, contained in the original material before reaction, subscripted as $\mathrm{p}$. It is given by the product of volume ( $\mathrm{V}$ in $\mathrm{cm}^{3}$ ), dry bulk density $\left(\rho\right.$ in $\left.\mathrm{g} / \mathrm{cm}^{3}\right)$, and elemental concentration ( $\mathrm{C}$ in weight \%). The mass of element $\mathrm{j}$ introduced into or out of the considered volume is indicated as $\mathrm{m}_{\mathrm{j}, \text { flux }}$ and is added to the mass of $\mathrm{j}$ in the system. Fluxes $\left(\mathrm{m}_{\mathrm{j}, \mathrm{flux}}\right)$ are positive if they enter the system and negative if they exit the system. On the right-hand side of Eq. 1, the mass of element $\mathrm{j}$ contained in the volume of reaction products, subscripted $\mathrm{w}$, is given by the product of the new volume, dry bulk density, and element concentration.

\subsection{Conservation equation of iron corrosion at $\mathrm{pH}>4.5$}

For iron corrosion, the element of concern is iron $(\mathrm{j}=\mathrm{Fe})$ which is distributed between the original metallic iron $\left(\mathrm{Fe}^{0}=\mathrm{ZVI}\right)$ and various iron hydroxides and oxides $(\mathrm{w}=\mathrm{ox})$. Eq. 1 can therefore be written as:

$$
\mathrm{V}_{\mathrm{ZVI}} \rho_{\mathrm{ZVI}} \mathrm{C}_{\mathrm{Fe}, \mathrm{ZVI}}+\mathrm{m}_{\mathrm{Fe}, \mathrm{flux}}=\mathrm{V}_{\text {ox }} \rho_{\text {ox }} \mathrm{C}_{\mathrm{Fe}, \mathrm{ox}}
$$

For $\mathrm{pH}>4.5$ the solubility of iron is very low and the flux of $\mathrm{Fe}\left(\mathrm{m}_{\mathrm{Fe}, \mathrm{flux}}\right)$ can be largely neglected assuming that water flow rate is slow enough that the dissolution/precipitation reactions are at pseudo-equilibrium. Eq. 2 can be re-written as:

$$
\mathrm{V}_{\mathrm{ZVI}} \rho_{\mathrm{ZVI}} \mathrm{C}_{\mathrm{Fe}, \mathrm{ZVI}}=\mathrm{V}_{\mathrm{ox}} \rho_{\mathrm{ox}} \mathrm{C}_{\mathrm{Fe}, \mathrm{ox}}
$$

Eq. 2a suggests that $\mathrm{V}_{\mathrm{ox}}$ (iron oxide) must be larger than $\mathrm{V}_{\mathrm{Fe}}$ (metallic iron) because all iron (hydr)oxides are less dense than $\mathrm{Fe}^{0}$ (Tab. 1).

\subsection{Volumetric strain}


106 With regard to iron corrosion driven volume changes, there are three possibilities: (i)

107 volumetric compression $\left(\mathrm{V}_{\mathrm{ZVI}}>\mathrm{V}_{\mathrm{ox}}\right)$, (ii) isovolumetric transformation $\left(\mathrm{V}_{\mathrm{ZVI}}=\mathrm{V}_{\mathrm{ox}}\right)$, and (iii)

108 volumetric expansion $\left(\mathrm{V}_{\mathrm{ZVI}}<\mathrm{V}_{\mathrm{ox}}\right)$. Accordingly, volumetric changes should be determined

109 experimentally. This is accomplished by using the classical definition of strain, $\varepsilon$, the ratio of

110 volume change in a process to the initial volume (Eq. 3):

111

$$
\varepsilon=\left(\mathrm{V}_{\mathrm{ox}}-\mathrm{V}_{\mathrm{ZVI}}\right) / \mathrm{V}_{\mathrm{ZVI}}=\left(\mathrm{V}_{\mathrm{ox}} / \mathrm{V}_{\mathrm{ZVI}}\right)-1
$$

112 Eq. 3 suggests that the volumetric strain is positive because $\mathrm{V}_{\text {ox }} / \mathrm{V}_{\mathrm{ZVI}} \geq 2.1$ [35].

113 In the next section, a new approach for the discussion of permeability loss will be given. This

114 exercise will be based on the recent paper by Henderson and Demond [11].

\section{Permeability loss in $\mathrm{Fe}^{\mathbf{0}} / \mathrm{H}_{2} \mathrm{O}$ systems}

116 The purpose of this section is to discuss the relative importance of mineral precipitation, gas

117 production and expansive iron corrosion for permeability loss in $\mathrm{Fe}^{0} / \mathrm{H}_{2} \mathrm{O}$ systems. Expansive

118 iron corrosion products included rust. To this end, the species discussed by Henderson and

119 Demond [11] will be considered individually (Table 1).

120 A cylindrical column apparatus for $\mathrm{Fe}^{0}$ filtration has an internal diameter (D), a reactive

121 length $\left(\mathrm{H}_{\mathrm{rz}}\right)$, and a subsequent total volume $\mathrm{V}_{\mathrm{rz}}\left(\mathrm{V}_{\mathrm{rz}}=\pi^{*} \mathrm{D}^{2} * \mathrm{H}_{\mathrm{rz}} / 4\right) . \mathrm{H}_{\mathrm{rz}}$ may be a fraction of

122 the length of the column apparatus $\left(\mathrm{H}_{\mathrm{rz}} \leq \mathrm{H}\right)$. A column may also contain several reactive

123 zones. The discussion herein is limited to a single reactive zone. The ratio of the initial

124 volume of the void space (inter-particular porosity) is $\Phi_{0}$ and the volume of pore is $\mathrm{Vp}=$

$125 \Phi_{0} * \mathrm{~V}_{\mathrm{rz}}$. The volume occupied by the solid particles $\mathrm{V}_{\text {solid }}$ is $\mathrm{V}_{\text {solid }}=\left(1-\Phi_{0}\right) * \mathrm{~V}_{\mathrm{rz}}$. Solid

126 particles include $\mathrm{Fe}^{0}$ and additives (e.g. gravel, pumice, sand), assumingly having the same

127 size and shape (roundness or sphericity). The following cylindrical column apparatus used by

128 Henderson and Demond [11] is considered: $\mathrm{D}=5 \mathrm{~cm}, \mathrm{H}_{\mathrm{rz}}=\mathrm{H}=25 \mathrm{~cm}$, a subsequent $\mathrm{V}_{\mathrm{rz}}=$

$129491.1 \mathrm{~cm}^{3}$, and initial porosities $\left(\Phi_{0}\right)$ of $0.62 . \Phi_{0}=0.62$ is also from ref. [11]. 
130 The challenge of the current work is to evaluate which quantity of each fouling species (iron

131 corrosion products) is necessary to occupy the initial pore volume (Vp).

\section{$132 \quad 3.1 \quad$ Filling the pore volume with individual minerals and $\mathbf{H}_{2}$ gas}

133 In this section, Eq. (4) assumes that $\mathrm{Fe}^{0}$ is oxidized by water. The initial pore volume (Vp) is

134 filled entirely by corrosion products $\left(\mathrm{H}_{2}\right.$ and $\mathrm{Fe}^{\mathrm{II}} / \mathrm{Fe}^{\mathrm{III}}$ species $)$ :

135

$136 \mathrm{t}_{0}=0$

$137 \mathrm{t}>\mathrm{t}_{0}$

$138 \mathrm{t}>\mathrm{t}_{0}$

$$
\text { y } \mathrm{H}_{2} \mathrm{O} \Rightarrow
$$$$
\mathrm{Fe}_{\mathrm{x}} \mathrm{O}_{\mathrm{y}}+
$$

0

$\mathrm{n}_{0} * \alpha / \mathrm{x}$

$\alpha^{*} n^{\prime}{ }_{0}$ $\mathrm{n}_{0}$

$\mathrm{n}_{0} *(1-\alpha)$

$\mathrm{x}^{*} \mathrm{n}^{\prime}{ }^{*}(1-\alpha)$ y $\mathrm{H}_{2} \uparrow$

0

$\mathrm{y}^{*} \mathrm{n}_{0} * \alpha / \mathrm{x}$

$\mathrm{y}^{*} \mathrm{n}^{\prime}{ }^{*} \alpha$

139 It is considered that the number of moles $\left(\mathrm{n}_{0}\right)$ of $\mathrm{Fe}^{0}$ at time $\mathrm{t}=0\left(\mathrm{t}_{0}\right)$ is a multiple of $\mathrm{n}_{0}\left(\mathrm{n}_{0}=\right.$

$140 \mathrm{x}^{*} \mathrm{n}^{\prime}{ }_{0}$ ). Accordingly, at $\mathrm{t}_{0}$, the reactive zone contains only $\mathrm{x}^{*} \mathrm{n}_{0}{ }_{0} \mathrm{Fe}^{0}$ (no oxide and no

141 hydrogen). At each time $\mathrm{t}\left(\mathrm{t}>\mathrm{t}_{0}\right)$, the residual number of moles of $\mathrm{Fe}^{0}$ is $\mathrm{x}^{*} \mathrm{n}^{\prime}{ }_{0} *(1-\alpha)$, the

142 number of mole of generated oxide is $\alpha^{*} n_{0} / x=\alpha^{*} n^{\prime}$ and the number of mole of $H_{2}$ is

$143 \mathrm{y}^{*} \mathrm{n}_{0}{ }^{*} \alpha / \mathrm{x}=\mathrm{y}^{*} \mathrm{n}^{\prime}{ }_{0}^{*} \alpha$ where $\alpha$ is the fraction of the initial amount of $\mathrm{Fe}^{0}$ which is depleted as a

144 function of time $(\mathrm{t})$. For iron hydroxides $\left(\mathrm{Fe}(\mathrm{OH})_{\mathrm{n}}\right)$ and carbonate $\left(\mathrm{FeCO}_{3}\right)$, the stoichiometry

145 of oxygen is taken as the value of " $\mathrm{x}$ " $(\mathrm{y}=\mathrm{x})$ because each mole of Fe releases one mole of

$146 \mathrm{H}_{2}($ for $\mathrm{n}=2)$.

147 Knowing the molar volume of individual oxides and $\mathrm{H}_{2}$ (Tab. 1), the degree of occupation of

148 the initial pore volume (Vp) can be evaluated. The reactive zone is clogged when enough 149 corrosion products $\left(\mathrm{Fe}_{\mathrm{x}} \mathrm{O}_{\mathrm{y}}\right.$ and $\left.\mathrm{H}_{2}\right)$ are produced to completely fill $\mathrm{Vp}$. In other words, bed 150 clogging corresponds to Eq. (5):

$$
\mathrm{V}_{\mathrm{ZVI}}+\mathrm{V}_{\mathrm{ox}}+\mathrm{V}_{\mathrm{H} 2}=\mathrm{V}_{\mathrm{rz}}
$$

152 The volume $\mathrm{V}_{\mathrm{i}}$ occupied by a species $\mathrm{i}$, is the product of its molar volume by the number of 153 moles. The equation of the clogging can be written as (Eq. 5a):

$$
\mathrm{V}_{\mathrm{m}, \mathrm{ZVI}}{ }^{*} \mathrm{x}^{*} \mathrm{n}^{\prime}{ }_{0}(1-\alpha)+\mathrm{V}_{\mathrm{m}, \mathrm{ox}}{ }^{*} \mathrm{n}^{\prime}{ }_{0}{ }^{*} \alpha+\mathrm{V}_{\mathrm{m}, \mathrm{H} 2}{ }^{*} \mathrm{n}^{\prime}{ }_{0}{ }^{*} \mathrm{y}^{*} \alpha=\mathrm{V}_{\mathrm{rz}}
$$


155 To have $\alpha$ values for individual oxides, it is sufficient to solve Eq. 5a. The solution is given 156 by Eq. $5 b$ :

$$
\alpha=\left[\mathrm{V}_{\mathrm{rz}} / \mathrm{x}^{*} \mathrm{n}^{\prime}{ }_{0}-\mathrm{V}_{\mathrm{m}, \mathrm{ZVI}}\right] /\left[\mathrm{V}_{\mathrm{m}, \mathrm{ox}} / \mathrm{x}+\mathrm{y} / \mathrm{x} * \mathrm{~V}_{\mathrm{m}, \mathrm{H} 2}-\mathrm{V}_{\mathrm{m}, \mathrm{ZVI}}\right]
$$

158 The porosity of granular sandy beds used in sand filters ranges from 0.40 to 0.50 (average of 159 0.45) [41]. The porosity of the filtration bed depends on several factors including grain size, 160 grain size distribution and shape (sphericity) of used particles [42]. The sphericity of the 161 medium is a measure of its roundness and ranges from 0.70 (angular grains) to about 0.90

162 (grains rounded by water or wind) $[41,43]$.

163 The volume of $\mathrm{Fe}^{0}\left(\mathrm{~V}_{\mathrm{Fe}}\right)$ in the pure $\mathrm{Fe}^{0}$ system $\left(100 \% \mathrm{Fe}^{0}\right)$ depends on the compactness $\mathrm{C}$ or 164 the porosity $\Phi\left(\mathrm{V}_{\mathrm{Fe}}=\mathrm{C}^{*} \mathrm{~V}_{\mathrm{RZ}}=(1-\Phi)^{*} \mathrm{~V}_{\mathrm{RZ}}\right)$. Reported operational values for the porosity of $165 \mathrm{Fe}^{0}$ systems vary between 40 and $70 \%[10,11,15]$. Calculations are made for the extreme 166 values of the porosity reported in peer-reviewed journal articles (36 and $62 \%) . \Phi_{0}=36 \%$ 167 corresponds to the ideal case of spherical materials [38]. The initial number of moles of $\mathrm{Fe}^{0}$ $168\left(\mathrm{n}_{0}\right)$ corresponding to the extreme cases are $41.4\left(\Phi_{0}=36 \%\right)$ and $24.6\left(\Phi_{0}=62 \%\right)$.

169 Calculations (Tab. 2) showed that if $\mathrm{H}_{2}$ does not escape from the reactive zone, the 170 consumption of less than $0.1 \%$ of the initial amount of $\mathrm{Fe}^{0}$ will be sufficient to clog the 171 systems. If this was likely to occur, the $\mathrm{Fe}^{0}$ filtration technology would have not been 172 possible.

173 Calculations assuming total escape of $\mathrm{H}_{2}$ gas out of the reactive zone $\left(\mathrm{V}_{\mathrm{m}, \mathrm{H} 2}=0\right.$ in Eq. $\left.5 b\right)$ 174 indicate that 16 to $62 \%$ of $\mathrm{Fe}^{0}$ can be depleted just at system clogging $\left(\Phi_{\text {to }}=0 \%\right)$ when the 175 initial porosity is $36 \%$. For $\Phi_{0}=62 \%, 46$ to $100 \% \mathrm{Fe}^{0}$ could be depleted just at system 176 clogging $(\alpha \geq 0.46)$. In other words, the sustainability of a $\mathrm{Fe}^{0}$ filtration system depends 177 strongly from its initial porosity $\left(\Phi_{0}\right)$.

178 The results herein suggest that, for $\Phi_{0}=36 \%$, when the main corrosion product is $\mathrm{Fe}_{3} \mathrm{O}_{4}$, 179 only $58 \%$ of $\mathrm{Fe}^{0}$ is consumed just at system clogging. This value in agreement with the value 
of $51 \%$ reported in former works [38]. The difference corresponds to different values used

181 for the volumetric expansion coefficient $(\eta) ; \eta=1.97$ herein vs. $\eta=2.08$ in ref. [37].

182 However, this approach fails to consider the in-situ generation of colloidal $\mathrm{Fe}{ }^{\mathrm{II}} / \mathrm{Fe}^{\mathrm{III}}$ species

183 and their further transformation to hydroxides and oxides $[44,45]$.

184 Eq. $5 \mathrm{~b}$ describes a pure iron bed $\left(100 \% \mathrm{Fe}^{0}\right)$. In the case that $\mathrm{Fe}^{0}$ is admixed with a non 185 expansive additive (e.g. gravel, pumice, sand) the initial number of moles of iron $\left(\mathrm{n}_{0}\right)$ has to 186 be corrected to the fraction of $\mathrm{n}_{0}$ corresponding to the volumetric proportion of $\mathrm{Fe}$ in the 187 reactive zone, e.g. $\mathrm{n}_{0} / 2$ for a system containing $50 \% \mathrm{Fe}^{0}(\mathrm{v} / \mathrm{v})$ and the balance amount of a 188 non porous material.

189 The results from Tab. 2 suggest that, at $\Phi_{0}=36 \%$, pure $\mathrm{Fe}^{0}$ beds are not sustainable as a rule 190 (see section 3.2.2). For larger initial porosity $\left(\Phi_{0}\right)$, more sustainable systems are obtained. 191 This result was already theoretically achieved by admixing $\mathrm{Fe}^{0}$ and porous media (e.g. 192 pumice). However, increased initial porosity as discussed here results from the geometry 193 (size, shape) of used media (e.g. $\mathrm{Fe}^{0}$, sand, gravel).

194 The influence of the shape of the $\mathrm{Fe}^{0}$ particles on the $\mathrm{Fe}^{0}$ bed porosity is schematically 195 represented in Fig. 1 as spherical (left) and cylindrical (right) $\mathrm{Fe}^{0}$ particles (black) are 196 progressively transformed to oxides (grey - rust). Fig. 1 confirms the fact that packed beds of 197 spherical media are the most compact [46-49]. This delineates the importance of 198 characterizing $\mathrm{Fe}^{0}$ and sand materials for their uniformity and sphericity and the resulting bed 199 for its compactness (porosity).

200 Another important feature seen in Tab. 2 ( $\alpha$ and $\alpha^{\prime}$ values) is that regardless from the 201 abundance of $\mathrm{Fe}^{0}$ in the system, bed clogging due to $\mathrm{H}_{2}$ gas production is likely to occur prior 202 to the consumption of $0.1 \% \mathrm{Fe}^{0}$. However, under the experimental conditions considered by 203 Henderson and Demond [11], gas accumulation is unlikely since the solutions were pumped 204 in upflow at a flow rate of $0.7 \mathrm{~mL} / \mathrm{min}$ into the columns. In addition, under field conditions, 
$\mathrm{H}_{2}$ consuming bacteria are ubiquitous [29]. In such cases, clogging is therefore more likely to

206 result from enhanced (bio-)stimulation (biofilm growth) and not from $\mathrm{H}_{2}$ accumulation.

207 The estimations in this section clearly show that if $\mathrm{H}_{2}$ was primarily responsible for bed 208 clogging, then it is unlikely that the $\mathrm{Fe}^{0} \mathrm{PRB}$ technology would have been effective on 209 medium to long-term timescales as observed in the field. PRB clogging would have been 210 prevalent before a fraction (less than $0.1 \%$ ) of the $\mathrm{Fe}^{0}$ had corroded. However, $\mathrm{H}_{2}$ gas may 211 contribute to permeability loss in association with particle 'cementation' (compaction) by 212 nascent iron hydroxides. In this case, compaction prohibits $\mathrm{H}_{2}$ escape and increases flow 213 resistance for pumped solutions.

\section{$214 \quad 3.2$ The process of permeability loss in $\mathrm{Fe}^{0} / \mathrm{H}_{2} \mathrm{O}$ systems}

215 In this section, a contemporary evaluation of permeability loss in the $\mathrm{Fe}^{0} / \mathrm{H}_{2} \mathrm{O}$ system is given.

216 The methodology is explicitly presented in ref. [38]. In the current work the following 217 assumptions apply:

218 (i) Uniform $\mathrm{Fe}^{0}$ corrosion: the radius reduction of spherical or cylindrical $\mathrm{Fe}^{0}$ particles is the 219 same for all particles;

220 (ii) the volume of the reactive zone $\left(\mathrm{V}_{\mathrm{rz}}\right)$ remains constant and the volume of granular 221 materials (e.g. sand) is not modified by the corrosion process;

222 (iii) $\mathrm{Fe}^{0}$ corrosion products are fluid enough to progressively fill available pore space.

223 As shown in section 2.3, iron corrosion occurs with concurrent volumetric expansion $(\eta=$ $224 \mathrm{~V}_{\mathrm{ox}} / \mathrm{V}_{\mathrm{ZVI}}>1$ ). The excess volume of $\mathrm{Fe}^{0}$ imbued by corrosion product formation is given by $225 \mathrm{~V}_{\text {excess }}$ in Eq. 6. By definition, $\mathrm{V}_{\text {excess }}$ is the difference between $\mathrm{V}_{\text {ox }}$ and $\mathrm{V}_{\mathrm{ZVI}}$ (Eq. 6).

$$
\mathrm{V}_{\text {excess }}=(\eta-1) * \mathrm{~V}_{\mathrm{ZVI}}
$$

227 The $\mathrm{Fe}^{0}$ filtration system is clogged when the volume $\mathrm{V}_{\text {excess }}$ is equal to the initial inter

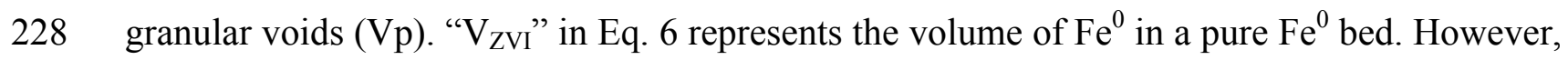
as discussed in sections 1 and $3.1, \mathrm{Fe}^{0}$ should be only a fraction of $\mathrm{V}_{\text {solid }}\left(\mathrm{V}_{\mathrm{ZVI}}=\tau_{\mathrm{ZVI}} * \mathrm{~V}_{\text {solid, }}\right.$,

230 with $\left.\tau_{\mathrm{ZVI}} \leq 1\right)$. Eq. 6 can be rewritten as: 


$$
(\eta-1) * \tau_{\mathrm{ZVI}} * \mathrm{~V}_{\text {solid }}=\mathrm{V}_{\text {excess }}
$$

232 Eq. 6a suggests that, for every $\eta$ value (i.e. every oxide), $V_{\text {excess }}$ is a linear function of $\tau_{\mathrm{ZVI}}$. To

233 find out at what extent $\tau_{\mathrm{ZVI}}$ contributes to complete pore filling, it is sufficient to graphically

234 solve Eq. 6a for $\mathrm{V}_{\text {excess }}=\mathrm{V}_{\mathrm{P}}$. Practically, there are two equivalent approaches: (i) solving

$235 \mathrm{~V}_{\text {excess }}-\mathrm{Vp}=0$ or (ii) solving $\mathrm{V}_{\text {excess }} / \mathrm{V}_{\mathrm{P}}=1$. The second approach is adopted in this work.

236 The solution of Eq. 6a (clogging) is the interception of the line $V_{\text {excess }} / V_{P}=f\left(\tau_{\mathrm{ZVI}}\right)$ with the line

$237100 \%$ (Fig. 2). Before discussing the actual evolution of the porosity, some fundamental

238 aspects for the solution of Eq. 6a will be given.

\section{$239 \quad$ 3.2.1 $\mathbf{F e}^{\mathbf{0}}$ filtration systems}

240 To date, $\mathrm{Fe}^{0}$ particles have been widely reported as successful for water treatment [50-53].

241 However, a holistic understanding of the $\mathrm{Fe}^{0} / \mathrm{H}_{2} \mathrm{O}$ system is yet to be achieved.

242 Fig. 2 represents the principle of $\mathrm{Fe}^{0}$ filtration beds. The origin (point $\mathrm{O}$ ) represent a $\mathrm{Fe}^{0}$-free

243 filter (e.g. activated alumina, activated carbon, gravel, pumice, sand, zeolite) and point

$244 \mathrm{I}(100,100)$ represents an "ideal $\mathrm{Fe}^{0}$-based filter" which becomes $100 \%$ clogged concurrent

245 with $100 \% \mathrm{Fe}^{0}$ depletion $\left(\mathrm{V}_{\text {excess }} / \mathrm{V}_{\mathrm{P}}=1\right)$. The line OI divides the graph into two halves.

246 Below OI, $\mathrm{V}_{\text {excess }} / \mathrm{V}_{\mathrm{P}}<100$ and the system is not clogged at $\mathrm{Fe}^{0}$ depletion. Above OI, $247 \mathrm{~V}_{\text {excess }} / \mathrm{V}_{\mathrm{P}}>100$ and the system is clogged before $\mathrm{Fe}^{0}$ depletion (a proportion of $\mathrm{Fe}^{0}$ is 248 wasted). Thus, Fig. 2 can be regarded as a useful reference tool for future work within this 249 field. Relevant parameters to complement Fig. 2 that will be investigated in future work 250 include: (i) the intrinsic reactivity of $\mathrm{Fe}^{0}$; (ii) the shape and size of $\mathrm{Fe}^{0}$; (iii) the shape and size 251 of sand; (iv) the dimensions and the geometry of the $\mathrm{Fe}^{0}$ bed; (v) the thickness of the $\mathrm{Fe}^{0} /$ sand 252 layer; (vi) the proportion of $\mathrm{Fe}^{0}$ in the $\mathrm{Fe}^{0}$ /sand layer; and (vii) the water flow velocity.

253 Point $\mathrm{O}$ in Fig. 2 represents all filtration designs without $\mathrm{Fe}^{0}$ (or another metallic element).

254 These include conventional slow sand filters (SSF), biosand filters (BSF) and iron oxidecoated sand filters. Considering filtration designs which entirely contain sandy materials, 256 point $\mathrm{O}$ can be limited to BSF and SSF. SSF have been used for water treatment since 1840 in 
Dijon/France by Henry Darcy [54]. BSF have been used for water treatment at household 258 level for over 20 years $[55,56]$. However, despite intensive research on BSF, their operating mode is yet to be completely understood $[42,43,55]$. For example, there are no established comprehensive design criteria for BSF [41,55,57]. Accordingly, the reproducibility and comparison of reported results from one setting to another is problematic. To fill this gap,

262 Kubare and Haarhoff [41] have provided the most recent systematic review for a rational 263 design of BSF. A Fe ${ }^{0}$ filtration system (Fig. 2) can be regarded as a modification of a SSF or BSF (point O). Therefore, it is essential to carefully develop rational and comprehensive engineering design criteria. In this effort, designing tools for BSF would be very helpful $266[41,55]$.

\subsubsection{The role of initial porosity in $\mathrm{Fe}^{0}$ bed clogging}

268 The theoretical discussion of $\mathrm{Fe}^{0} \mathrm{PRB}$ porosity until now was focused on the case of maximum compactness for which the initial porosity is $0.36\left(\Phi_{0}=36 \%\right)$ [32]. For such systems, a pure $\mathrm{Fe}^{0}$ bed is clogged when less than $60 \%$ of the initial amount of $\mathrm{Fe}^{0}$ is depleted (section 3.1). According to Fig. 1, for $\Phi_{0}=36 \%$, all Fe ${ }^{0}$ beds are situated above line OI. However, significantly larger porosity values have typically been reported in the literature, the highest being $62 \%$ by Henderson and Demond [11]. Accordingly, this section discusses the evolution of the porosity of a conventional sand filter $\left(0 \% \mathrm{Fe}^{0}\right)$ as it is progressively transformed to a pure $\mathrm{Fe}^{0}$ filter $\left(100 \% \mathrm{Fe}^{0}\right)$. Particular attention is paid to the extreme values of the porosity $\left(\Phi_{0}=36\right.$ and $\left.62 \%\right)$. The results are summarized in Fig. 3.

The ideal line OI is not represented in Fig. 3 for clarity. Instead the point $\mathrm{I}(100,100)$ is 278 represented. Fig. 3a $\left(\Phi_{0}=0.36\right)$ shows clearly that all systems are clogged before $\mathrm{Fe}^{0}$ 279 depletion has been occurred. In contrast, Fig. 3b shows that, for an initial porosity $\left(\Phi_{0}\right)$ of $2800.62, \mathrm{Fe}^{0}$ beds are sustainable if magnetite $\left(\mathrm{Fe}_{3} \mathrm{O}_{4}\right)$, maghemite $\left(\gamma-\mathrm{Fe}_{2} \mathrm{O}_{3}\right)$ and hematite $281\left(\mathrm{Fe}_{2} \mathrm{O}_{3}\right)$ are the sole iron corrosion products. Additionally, it shows that ferrous hydroxide $282\left(\mathrm{Fe}(\mathrm{OH})_{2}\right)$ is the "ideal corrosion product" for the $\mathrm{Fe}^{0} \mathrm{PRB}$ to clog concurrent with $\mathrm{Fe}^{0}$ 
depletion. With the formation of ferrous hydroxide, magnetite, maghemite and hematite being more prevalent in anoxic conditions, it can therefore be stated that $\mathrm{Fe}^{0} \mathrm{PRBs}$ are most ideally suited for oxygen depleted or anoxic conditions.

Magnetite $\left(\mathrm{x}_{\mathrm{Fe}}=72.4 \%\right.$, Tab.1) may result from $\mathrm{Fe}(\mathrm{OH})_{2}$ dehydration under anoxic conditions and is therefore the sole mineral, that is likely to be quantitatively generated from anoxic $\mathrm{Fe}^{0}$ corrosion.

\subsubsection{Discussion}

The presentation until now has focused on the evolution of the permeability loss as a key factor for the sustainability of $\mathrm{Fe}^{0} \mathrm{PRB}$ systems. $\mathrm{A} \mathrm{Fe}{ }^{0}$ filtration system is sustainable only if it can maintain hydraulic (permeability) performance while also remaining effective for pollutant removal. In other words, a permeable but non reactive $\mathrm{Fe}^{0}$ filtration system is useless.

A Fe ${ }^{0}$ filtration system can be considered both a chemical and physical water filter device, with its efficacy dictated by progressive expansion/compression cycles during aqueous corrosion [52]. In a $\mathrm{Fe}^{0}$ filtration system, chemical reactions included (i) iron oxidative dissolution, (ii) polymerisation of iron hydroxides and, (iii) subsequent precipitation of hydroxides and oxides. Quantitative chemical transformations (oxidation/reduction) of dissolved species may also occur. However, resulted species must be removed from the aqueous phase by a physical process: adsorption, occlusion, size-exclusion. Accordingly, $\mathrm{Fe}^{0}$ is not a strong reducing agent under environmental conditions as widely accepted [5-7,10]. More importantly, reduction is not a stand alone contaminant removal mechanism [58-61]. Rather, $\mathrm{Fe}^{0}$ is a generator of contaminant scavengers for reactive filtration [44,62-65]. While adsorptive filtration has been mostly used for metal removal [62-65], the affinity of organic compounds for iron hydroxide/oxides (corrosion products) is well documented [66-71]. For example, Saha et al. [71] investigated the adsorptive removal of seven different dyes on iron 
oxide nanoparticles an reported on enhanced adsorption capacity of the dyes containing

309 hydroxyl (-OH) (erichrome black-T, bromophenol blue, bromocresol green, and fluorescein).

310 For the proper scaling of $\mathrm{Fe}^{0}$-supported sand filters as reactive filtration device, factor

311 sustaining size exclusion should be understood and optimised [72]: (i) the pore size must be

312 small enough for sufficient contaminant removal; or (ii) used $\mathrm{Fe}^{0}$ must be reactive enough to

313 produce a sufficient amount of 'scavengers' as a function of time. Alternatively, the thickness

314 of the $\mathrm{Fe}^{0} \mathrm{PRB}$ can be increased to improve the devices filtration capacity.

315 This highlights the importance of characterizing the intrinsic reactivity of $\mathrm{Fe}^{0}$ materials prior

316 to application [73]. Ideally, the selection of a $\mathrm{Fe}^{0}$ material for a particular site should be

317 governed by its intrinsic reactivity (and porosity when incorporated in the PRB system) and

318 the expected impact of local geochemical (and geophysical) conditions on these factors. In

319 cases where contaminant breakthrough was observed despite insignificant permeability loss,

320 two explanations can be suggested: (i) the material is not reactive enough to generate

321 "scavengers" in sufficient quantities, (ii) clogging of the entrance zone has disturbed the flow

322 regime and preferential flow paths are created in the system. Preferential flow paths

323 significantly impair the contact of flowing water with bed media (collectors, iron, sand).

\section{$324 \quad 4 \quad$ Conclusions}

325 Correlating the fundamental relationship between $\mathrm{Fe}^{0}$ PRB permeability loss and groundwater

326 chemistry is extremely important for the design of sustainable $\mathrm{Fe}^{0}$ remediation systems.

327 Further developments require knowledge of the intrinsic reactivity of $\mathrm{Fe}^{0}$, the rate of the

328 formation of corrosion products and the role of foreign detrital minerals. Using mathematical

329 modelling, the present communication challenges both the prevailing view and the

330 contribution of Henderson and Demond [11]. An extensive mass balance analysis of aqueous

331 iron corrosion has been used to show that volumetric expansion is the major control on

332 permeability loss. It has been shown that, whilst $\mathrm{Fe}^{0}$ filtration systems (including PRBs)

333 operating in anoxic (phreatic zone) conditions can exhibit limited permeability loss due to $\mathrm{Fe}^{0}$ 
334 corrosion product formation, $\mathrm{Fe}^{0}$ filtration systems operating in oxic (vadose zone) conditions

335 exhibit significantly high permeability loss. It can therefore be concluded that admixing $\mathrm{Fe}^{0}$

336 with a non expansive materials (e.g. gravel, $\mathrm{MnO}_{2}$, pumice, sand) is a prerequisite for any

337 sustainable $\mathrm{Fe}^{0}$ filtration systems operating in the near surface geosphere.

338 The present work and related studies have delineated the early development of the $\mathrm{Fe}^{0} \mathrm{PRB}$

339 technology that was marked by empirical designs [37,38,74,75-80]. Field experiences from

340 more than 120 reactive barriers and an innumerable numbers of filters (including laboratory

341 columns) worldwide should be used to continuously refine this innovative technology.

342 Clearly the $\mathrm{Fe}^{0}$ technology should now be translated into rational engineering design criteria.

343 As there are no established comprehensive design criteria for $\mathrm{Fe}^{0}$ beds, the reproducibility and

344 comparison of available results is problematic. For example, despite the established

345 significance of particle shape and size on the permeability, these parameters are not routinely

346 given when describing operational conditions. Similarly, the initial porosity is not always

347 given and the contribution of iron corrosion products to its filling was not properly addressed.

348 A tentative guideline for future laboratory experiments can also be concluded: (i) assess the

349 intrinsic reactivity of used $\mathrm{Fe}^{0}$, (ii) define the size and sphericity of all used materials $\left(\mathrm{Fe}^{0}\right.$ and

350 admixing materials), (iii) consider the surface roughness of $\mathrm{Fe}^{0}$ and sand grains, (iv)

351 characterize the dimension and the composition of used columns, (v) evaluate the porosity of

352 resulted columns, (vi) characterize used initial solutions (e.g. pH, Eh, $\mathrm{O}_{2}$ level,

353 contamination), (vii) record the time dependant volume of the column effluent, and (viii)

354 characterize the column effluent for $\mathrm{pH}$, Eh, dissolved iron, target contaminants.

\section{Acknowledgments}

356 The manuscript was improved by the insightful comments of anonymous reviewers from

357 CLEAN Soil, Air, Water.

\section{References}

359 [1] D. Blowes, Tracking hexavalent Cr in groundwater. Science 2002, 295, 2024-2025. 
[2] J.L. Jambor, M. Raudsepp, K. Mountjoy, Mineralogy of permeable reactive barriers for the attenuation of subsurface contaminants. Can. Miner. 2005, 43, 2117-2140.

362 [3] K. Komnitsas, G. Bartzas, I. Paspaliaris, Inorganic contaminant fate assessment in zerovalent iron treatment walls. Environ. Forensics 2006, 7, 207-217.

364 [4] K. Komnitsas, G. Bartzas, I. Paspaliaris, Modeling of reaction front progress in fly ash permeable reactive barriers. Environ. Forensics 2006, 7, 219-231.

[5] A.D. Henderson, A.H. Demond, Long-term performance of zero-valent iron permeable reactive barriers: a critical review. Environ. Eng. Sci. 2007, 24, 401-423.

[6] A.B. Cundy, L. Hopkinson, R.L.D. Whitby, Use of iron-based technologies in contaminated land and groundwater remediation: A review. Sci. Tot. Environ. 2008,

[7] R. Thiruvenkatachari, S. Vigneswaran, R. Naidu, Permeable reactive barrier for groundwater remediation. J. Ind. Eng. Chem. 2008, 14, 145-156.

[8] S. Comba, A. Di Molfetta, R. Sethi, A Comparison between field applications of nano-, micro-, and millimetric zero-valent iron for the remediation of contaminated aquifers. Water Air Soil Pollut. 2011, 215, 595-607.

[9] M. Gheju, Hexavalent chromium reduction with zero-valent iron (ZVI) in aquatic systems. Water Air Soil Pollut. 2011, 222, 103-148.

[10] ITRC, Permeable reactive barrier: Technology update. PRB-5. Washington, D.C.: Interstate Technology \& Regulatory Council, PRB: Technology Update Team (2011). www.itrcweb.org (access: 09.03.2012)

[11] A.D. Henderson, A.H. Demond, Impact of solids formation and gas production on the 382 permeability of ZVI PRBs. J. Environ. Eng. 2011, 137, 689-696.

[12] N. Muchitsch, T. Van Nooten, L. Bastiaens, P. Kjeldsen, Integrated evaluation of the performance of a more than seven year old permeable reactive barrier at a site 
contaminated with chlorinated aliphatic hydrocarbons (CAHs). J. Contam. Hydrol. 2011, 126, 258-270.

387 [13] S. Ulsamer, A model to characterize the kinetics of dechlorination of tetrachloroethylene and trichloroethylene by a zero valent iron permeable reactive barrier. Master thesis, Worcester Polytechnic Institute, 2011, 73 pp.

[14] E. Bi, J.F. Devlin, B. Huang, Effects of mixing granular iron with sand on the kinetics of trichloroethylene reduction. Ground Water Monit. Remed. 2009, 29, 56-62.

[15] Y.H. Kim, S.-O. Ko, H.C. Yoo, Simultaneous removal of tetrachlorocarbon and chromium(VI) using zero valent iron. J. Korean Soc. Environ. Eng. 2002, 24, 1949 1956.

[16] D.-I. Song, Y.H. Kim, W.S. Shin, A simple mathematical analysis on the effect of sand in $\mathrm{Cr}(\mathrm{VI})$ reduction using zero valent iron. Korean J. Chem. Eng. 2005, 22, 67-69.

[17] N. Moraci, P.S. Calabrò, Heavy metals removal and hydraulic performance in zerovalent iron/pumice permeable reactive barriers. J. Environ. Manage. 2010, 91, 23362341

400

401

[18] G. Bartzas, K. Komnitsas, Solid phase studies and geochemical modelling of low-cost permeable reactive barriers. J. Hazard. Mater. 2010, 183, 301-308.

402

403

[19] L. Li, C.H. Benson, Evaluation of five strategies to limit the impact of fouling in permeable reactive barriers. J. Hazard. Mater. 2010, 181, 170-180.

404 [20] M.S. Odziemkowski, T.T. Schuhmacher, R.W. Gillham, E.J. Reardon, Mechanism of oxide film formation on iron in simulating groundwater solutions: Raman spectroscopic studies. Corros. Sci. 1998, 40, 371-389.

407

[21] S. Yabusaki, K. Cantrell, B. Sass, C. Steefel, Multicomponent reactive transport in an in 408 situ zero-valent iron cell. Environ. Sci. Technol. 2001, 35, 1493-1503. 
[22] R. Venkatapathy, D.G. Bessingpas, S. Canonica, J.A. Perlinger, Kinetic models for trichloroethylene transformation by zero-valent iron. Appl. Catal. Environ. 2002, 37, $139-159$.

[23] R.T. Wilkin, R.W. Puls, G.W. Sewell, Long-term performance of permeable reactive barriers using zero-valent iron: Geochemical and microbiological effects. Ground Water 2002, 41, 493-503.

[24] R.L. Johnson, R.B. Thoms, R.O'B. Johnson, T. Krug, Field evidence for flow reduction through a zero-valent iron permeable reactive barrier. Ground Water Monit. Remed. 2008, 28, 47-55.

[25] R.L. Johnson, R.B. Thoms, R.O'B. Johnson, J.T. Nurmi, P.G. Tratnyek, Mineral precipitation upgradient from a zero-valent iron permeable reactive barrier. Ground Water Monit. Remed. 2008, 28, 56-64.

[26] M. Odziemkowski, Spectroscopic studies and reactions of corrosion products at surfaces and electrodes. Spectrosc. Prop. Inorg. Organomet. Compd. 2009, 40, 385-450.

[27] S.W. Orth, R.W. Gillham, Dechlorination of trichloroethene in aqueous solution using $\mathrm{Fe}^{0}$. Environ. Sci. Technol. 1996, 30, 66-71.

[28] Y. Zhang, R.W. Gillham, Effects of gas generation and precipitates on performance of $\mathrm{Fe}^{0}$ PRBs. Ground Water 2005, 43, 113-121.

[29] M.J. Wildman, P.J.J. Alvarez, RDX degradation using an integrated Fe(0)-microbial treatment approach. Water Sci. Technol. 2001, 43, 25-33.

[30] S. Biswas, P. Bose, Zero-valent iron assisted autotrophic denitrification. J. Environ. Eng. ASCE 2005, 131, 1212-1220.

[31] S.-M. Wang, S.-k. Tseng, Reductive dechlorination of trichloroethylene by combining autotrophic hydrogen-bacteria and zero-valent iron particles. Biores. Technol. 2009, $100,111-117$. 
434 [32] T. Van Nooten, D. Springael, L. Bastiaens, Positive impact of microorganisms on the

435

436

437

438

439

440

441

442

443

444

445

446

447

448

449

450

451

452

453

454

455

456

457

458 performance of laboratory-scale permeable reactive iron barriers. Environ. Sci. Technol. 2008, 42, 1680-1686.

[33] N.B. Pilling, R.E. Bedworth, The oxidation of metals at high temperatures. J. Inst. Metals 1923, 29, 529-591.

[34] K. Suda, S. Misra, K. Motohashi, Corrosion products of reinforcing bars embedded in concrete. Corros. Sci. 1993, 35, 1543-1549.

[35] S. Caré, Q.T. Nguyen, V. L'Hostis, Y. Berthaud, Mechanical properties of the rust layer induced by impressed current method in reinforced mortar. Cement Concrete Res. 2008, 38, 1079-1091.

[36] Y. Zhao, H. Ren, H. Dai, W. Jin, Composition and expansion coefficient of rust based on X-ray diffraction and thermal analysis. Corros. Sci. 2011, 53, 1646-1658.

[37] C. Noubactep, Aqueous contaminant removal by metallic iron: Is the paradigm shifting? Water SA 2011, 37, 419-426.

[38] C. Noubactep, S. Caré, K.B.D. Btatkeu, C.P. Nanseu-Njiki, Enhancing the sustainability of household $\mathrm{Fe}^{0}$ /sand filters by using bimetallics and $\mathrm{MnO}_{2}$. Clean - Soil, Air, Water 2012, 40, 100-109.

[39] G.H. Brimhall, J.L. Christopher, C. Ford, J. Bratt, G. Taylor, O. Warin, Quantitative geochemical approach to pedogenesis: importance of parent material reduction, volumetric expansion, and eolian influx in lateritization. Geoderma 1991, 51, 51-91.

[40] R. Balasubramaniam, K.A.V. Ramesh, P. Dillmann, Characterization of rust on ancient Indian iron. Curr. Sci. 2003, 85, 1546-1555.

[41] M. Kubare, J. Haarhoff, Rational design of domestic biosand filters. J. Water Supply: Res. Technol. - AQUA 2010, 59, 1-15.

[42] K.P. Panayiotopoulos, Packing of sands - a review. Soil Tillage Res. 1989, 13, 101-121. 
[43] J. Haarhoff, A. Vessal, A falling-head procedure for the measurement of filter media sphericity. Water SA 2010, 36, 97-104.

[44] K.-M. Yao, M.T. Habibian, C.R. O’melia, Water and waste water filtration: concepts and applications. Environ. Sci. Technol. 1971, 5, 1105-1112.

[45] P. Bedrikovetsky, F.D. Siqueira, C.A. Furtado, A.L.S. Souza, Modified particle detachment model for colloidal transport in porous media. Transp. Porous Med. 2011, $86,353-383$.

[46] W.O. Smith, P.D. Foote, P.F. Busang, Packing of homogeneous spheres. Phys. Rev. 1929, 34, 1271-1274.

[47] E. Manegold, R. Hofmann, K. Solf, Ueber Kapillarsysteme XII. I. Die mathematische Behandlung idealer Kugelpackungen und das Hohlraumvolumen realer Gerüststrukturen. Colloid Polymer Sci. 1931, 56, 142-159.

[48] H. Iwata, T. Homma, Distribution of coordination numbers in random packing of homogeneous spheres. Powder Technol. 1994, 10, 79-83.

[49] Neto, L.N., Kotousov, A. \& Bedrikovetsky, P. Application of contact theory to evaluation of elastic properties of low consolidated porous media. Int. J. Fract. 2011, $168,267-276$.

[50] A. Hussam, A.K.M. Munir, A simple and effective arsenic filter based on composite iron matrix: Development and deployment studies for groundwater of Bangladesh. $J$. Environ. Sci. Health A 2007, 42, 1869-1878.

[51] M.A. Shannon, P.W. Bohn, M. Elimelech, J.G. Georgiadis, B.J. Marinas, A.M. Mayes,Science and technology for water purification in the coming decades. Nature 2008, 452, 301-310.

[52] C. Noubactep, Metallic iron for safe drinking water worldwide. Chem. Eng. J. 2010, 165, 740-749. 
[53] D.E. Giles, M. Mohapatra, T.B. Issa, S. Anand, P. Singh, Iron and aluminium based adsorption strategies for removing arsenic from water. J. Environ. Manage. 2011, 92, $3011-3022$

[54] H. Darcy, Les fontaines publiques de la Ville de Dijon. V. Dalmont, Paris (1856) 647 pp.

[55] T.O. Mahlangu, B.B. Mamba, M.N.B. Momba, A comparative assessment of chemical contaminant removal by three household water treatment filters. Water SA 2012, 38, $39-48$.

[56] C.E. Stauber, E.R. Printy F.A. McCarty, K.R. Liang, M.D. Sobsey, Cluster randomized controlled trial of the plastic biosand water filter in Cambodia. Environ. Sci. Technol. 2012, 46, 722-728.

[57] M. Lea, Biological sand filters: Low-cost bioremediation technique for production of clean drinking water. Current Protocols Microbiol. 1G.1.1-1G.1.28 2008, doi: 10.1002/9780471729259.mc01g01s9.

[58] C. Noubactep, Processes of contaminant removal in " $\mathrm{Fe}^{0}-\mathrm{H}_{2} \mathrm{O}$ " systems revisited. The importance of co-precipitation. Open Environ. J. 2007, 1, 9-13.

[59] C. Noubactep, A critical review on the mechanism of contaminant removal in $\mathrm{Fe}^{0}-\mathrm{H}_{2} \mathrm{O}$ systems. Environ. Technol. 2008, 29, 909-920.

[60] C. Noubactep, The suitability of metallic iron for environmental remediation. Environ. Progr. Sust. En. 2010, 29, 286-291.

[61] C. Noubactep, The fundamental mechanism of aqueous contaminant removal by metallic iron. Water SA 2010, 36, 663-670.

[62] M. Edwards, M. Benjamin, Adsorptive filtration using coated sand: A new approach for treatment of metal-bearing wastes. J. Water Pollut. Control Fed. 1989, 61, 1523-1533.

[63] A.H. Khan, S.B. Rasul, A.K.M. Munir, M. Habibuddowla, M. Alauddin, S.S. Newaz, A. Hussam, Appraisal of a simple arsenic removal method for groundwater of Bangladesh. J. Environ. Sci. Health A 2000, 35, 1021-1041. 
510 [64] D. Dermatas, X. Meng, Removal of As, Cr and Cd by adsorptive filtration. Global Nest: the Int. J. 2004, 6, 73-80.

512 [65] S. Roy, P. Bose, Modeling arsenite adsorption on rusting metallic iron. J. Environ. Eng. 2010, 136, 405-411.

514 [66] K. Hanna, Adsorption of aromatic carboxylate compounds on the surface of synthesized iron oxide-coated sands. Appl. Geochem. 2007, 22, 2045-2053.

516 [67] K. Hanna, Sorption of two aromatic acids onto iron oxides: Experimental study and modeling. J. Colloid Interf. Sci. 2007, 309, 419-428.

[68] K. Eusterhues, F.E. Wagner, W. Häusler, M. Hanzlik, H. Knicker, K.U. Totsche, I. Kögel-Knabner, U. Schwertmann, Characterization of ferrihydrite-soil organic matter coprecipitates by X-ray diffraction and Mössbauer spectroscopy. Environ. Sci. Technol. 2008, 42, 7891-7897.

[69] K. Hanna, J.-F. Boily, Sorption of two naphthoic acids to goethite surface under flow through conditions. Environ. Sci. Technol. 2010, 44, 8863-8869.

[70] K. Eusterhues, T. Rennert, H. Knicker, I. Kgel-Knabner, K.U. Totsche, U. Schwertmann, Fractionation of organic matter due to reaction with ferrihydrite: Coprecipitation versus adsorption. Environ. Sci. Technol. 2011, 45, 527-533.

[71] B. Saha, S. Das, J. Saikia, G. Das, Preferential and enhanced adsorption of different dyes on iron oxide nanoparticles: A comparative study. J. Phys. Chem. C 2011; 115, 80248033.

530 [72] U. Förstner, P. Jacobs, F. v. d. Kammer, Impact of natural nanophases on heavy-metal retention in zeolite-supported reactive filtration facilities for urban run-off treatment. Fresenius J. Anal. Chem. 2001, 371, 652-659.

[73] C. Noubactep, T. Licha, T.B. Scott, M. Fall, M. Sauter, Exploring the influence of operational parameters on the reactivity of elemental iron materials. J. Hazard. Mater. 2009, 172, 943-951. 
536 [74] A. Ghauch, H. Abou Assi, H. Baydoun, A.M. Tuqan, A. Bejjani, Fe ${ }^{0}$-based trimetallic systems for the removal of aqueous diclofenac: Mechanism and kinetics. Chem. Eng. J. 2011, 172, 1033-1044.

[75] R.A. Crane, T.B. Scott, Nanoscale zero-valent iron: future prospects for an emerging water treatment technology. J. Hazard. Mater. 2012, 211-212, 112-125.

[76] C. Noubactep, S. Caré, R.A. Crane, Nanoscale metallic iron for environmental remediation: prospects and limitations. Water Air Soil Pollut. 2012, 223, 1363-1382.

[77] C. Noubactep, Metallic iron for water treatment: A knowledge system challenges mainstream science. Fresenius Environ. Bull. 2011, 20, 2632-2637.

[78] C. Noubactep, E. Temgoua, M.A. Rahman, Designing iron-amended biosand filters for decentralized safe drinking water provision. Clean: Soil, Air, Water 2012, doi: 10.1002/clen.201100620.

[79] C. Noubactep, Investigating the processes of contaminant removal in $\mathrm{Fe}^{0} / \mathrm{H}_{2} \mathrm{O}$ systems. Korean J. Chem. Eng. 2012, doi: 10.1007/s11814-011-0298-8.

[80] R. Crane, C. Noubactep, Elemental metals for environmental remediation: learning from hydrometallurgy. Fresenius Environ. Bull. 2012, 21, 1192-1196. 
553 Table 1: Some characteristics of metallic iron $\left(\mathrm{Fe}^{0}\right)$ and its main corrosion products commonly identified in $\mathrm{Fe}^{0}$ PRBs. "x" is the weight percent of $\mathrm{Fe}$ in the phase. As a rule, oxides formed under anoxic conditions exhibit larger $x$ values. " $\eta$ " is the calculated coefficient of volumetric expansion. Phase parameters are compiled from Balasubramaniam et al. [40] and Henderson and Demond [11].

558

\begin{tabular}{lllllll}
\hline Phase & Name & Structure & Density & $\mathbf{V}_{\mathbf{m}}$ & $\mathbf{x}$ & $\eta$ \\
& & & $\left(\mathrm{g} / \mathrm{cm}^{3}\right)$ & $\left(\mathrm{cm}^{3} / \mathrm{mol}\right)(\%)$ & $(-)$ \\
\hline $\mathrm{Fe}^{0}$ & Iron metal & bcc & 7.86 & 7.6 & 100.0 & - \\
$\mathrm{Fe}(\mathrm{OH})_{3}$ & $\mathrm{Fe}^{\mathrm{III}}$ hydroxide & perovskite-like & 3.1 & 34.4 & 52.0 & 4.53 \\
$\mathrm{FeCO}_{3}$ & Siderite & Trigonal & 3.83 & 29.3 & 48.3 & 3.86 \\
$\mathrm{Fe}(\mathrm{OH})_{2}$ & $\mathrm{Fe}^{\mathrm{II}}$ hydroxide & Trigonal & 3.4 & 26.4 & 62.2 & 3.47 \\
$\alpha-\mathrm{FeOOH}$ & Goethite & Orthorhombic & 4.28 & 20.3 & 62.9 & 2.67 \\
$\gamma-\mathrm{Fe}_{2} \mathrm{O}_{3}$ & Maghemite & Cubic & 4.69 & 29.1 & 70.0 & 1.91 \\
$\alpha-\mathrm{Fe}_{2} \mathrm{O}_{3}$ & Hematite & Trigonal & 5.3 & 30.1 & 70.0 & 1.98 \\
$\mathrm{Fe}_{3} \mathrm{O}_{4}$ & Magnetite & Cubic & 5.175 & 45.0 & 72.4 & 1.97 \\
\hline
\end{tabular}


561 Table 2: Estimation of the extent of $\mathrm{Fe}^{0}$ depletion ( $\alpha$ value in $\%$ ) in the column of Henderson 562 and Demond [11] for two values of the initial bed porosity. $\alpha$ and $\alpha_{1}$ correspond to $\Phi_{0}=36 \%$

563 when $\mathrm{H}_{2}$ remains in the system or escapes respectively and $\alpha^{\prime}$ and $\alpha_{1}^{\prime}$ correspond to $\Phi_{0}=62$

$564 \%$ when $\mathrm{H}_{2}$ remains in the system or escapes respectively. It is seen that in all cases the initial

565 porosity is filled by gas when less than $0.1 \%$ of the initial mass of $\mathrm{Fe}^{0}$ is corroded. A value of $566100 \%$ is related to a system which is not clogged when $\mathrm{Fe}^{0}$ is depleted.

567

568

\begin{tabular}{lccccc}
\hline Name & Formula & \multicolumn{3}{c}{$\alpha$ values (\%) } \\
& & $\alpha$ & $\alpha$ & $\alpha$ & $\alpha_{1}{ }_{1}$ \\
\hline Maghemite & $\mathrm{Fe}_{2} \mathrm{O}_{3}$ & 0.01 & 62 & 0.04 & 100 \\
Magnetite & $\mathrm{Fe}_{3} \mathrm{O}_{4}$ & 0.01 & 58 & 0.04 & 100 \\
Hematite & $\mathrm{Fe}_{2} \mathrm{O}_{3}$ & 0.01 & 57 & 0.04 & 100 \\
Goethite & $\mathrm{FeOOH}$ & 0.02 & 34 & 0.06 & 98 \\
Ferrous hydroxide & $\mathrm{Fe}(\mathrm{OH})_{2}$ & 0.02 & 24 & 0.06 & 70 \\
Siderite & $\mathrm{FeCO}$ & 0.02 & 20 & 0.06 & 57 \\
Ferric hydroxide & $\mathrm{Fe}(\mathrm{OH})_{3}$ & 0.02 & 16 & 0.06 & 46 \\
& & & & & \\
\hline
\end{tabular}




\section{Figure captions}

571

572 Figure 1: Comparison of the evolution of porosity loss in a $\mathrm{Fe}^{0}$ bed filled with spherical (left) and cylindrical (right) particles. The compactness is maximal for spherical particles. The roundness or sphericity of used materials ( $\mathrm{Fe}^{0}$ and additives) should be routinely characterized as this is crucial for the initial porosity.

576 Figure 2: Types of $\mathrm{Fe}^{0}$-based filters for water treatment. The point $\mathrm{O}(0.0)$ represents a $\mathrm{Fe}^{0}$ free filter (e.g. biosand filter, iron oxide-amended sand). The point $\mathrm{I}(100,100)$ correspond to a filter which is clogged just at $\mathrm{Fe}^{0}$ depletion.

579 Figure 3: Evolution of the residual porosity as function of the volumetric proportion of $\mathrm{Fe}^{0}$ is the filter for the two extreme values of the initial porosity $\left(\Phi_{0}=0.36\right.$ and 0.62$)$. It is seen that for $\Phi_{0}=0.36$ no filter is sustainable. For $\Phi_{0}=0.62$, filter operating under strictly anoxic conditions are sustainable. 